\title{
Comparative Studies on Growth and Development of Heat-Tolerant and Non Heat-Tolerant Tomato Plants Grown at Different Root-Zone Temperatures
}

\author{
George Oduro Nkansah and Tadashi Ito \\ Faculty of Horticulture, Chiba University, Matsudo, Chiba 271
}

\begin{abstract}
Summary
Comparative studies on growth and development of young heat-tolerant tomato (Lycopersicon esculentum Mill. cv. Shuki) and non heat-tolerant one (cv. Sataan) grown under four root-zone temperatures (RZT) were carried out. Growth rates were measured at RZT of $15^{\circ}, 20^{\circ}, 25^{\circ}$, and $30^{\circ} \mathrm{C}$. Plants in study 1 , were grown for 10 days ( 21 to 31 days after sowing) and in study 2,21 days (21 to 42 days after sowing). Optimum growth in both cultivars occurred at $30^{\circ} \mathrm{C}$ in plants grown for 10 days and at $25^{\circ}-30^{\circ} \mathrm{C}$ in plants grown for 21 days. Cultivar 'Shuki' had greater shoot fresh and dry weight, greater root dry weight and greater leaf area than 'Sataan' at all RZT. Cultivar 'Shuki' had greater NAR compared to 'Sataan' at all RZT. Significant and possitive correlations existed among growth parameters at all RZT in both cultivars. Biomass or carbohydrate production between the two cultivars at the end of 21 days was significantly different at RZT of $20^{\circ} \mathrm{C}$ and $25^{\circ} \mathrm{C}$. The results indicate that the heat-tolerant cultivar, 'Shuki', is a better biomass or carbohydrate producer than the non heat-tolerant cultivar, 'Sataan'.
\end{abstract}

\section{Introduction}

The effect of root-zone temperature on growth of non heat-tolerant tomato cultivars has been stud ied extensively. The optimum root-zone temperature for seedling growth of tomato is between $27^{\circ}$ $\sim 32^{\circ} \mathrm{C}$ when the air temperature is between $17^{\circ}$ $\sim 25^{\circ} \mathrm{C}$ (Hurewitz and Janes, 1983 ). Yelle et al. (1987) reported maximal root growth at $25^{\circ} \mathrm{C}$ and Cooper (1974) found that shoot growth of tomato plants was highest at $30^{\circ} \mathrm{C}$ when the air temperatures were $23^{\circ} / 16^{\circ} \mathrm{C} \pm 1^{\circ} \mathrm{C}$ day/night. Abdelhafeez et al. (1971) and Orchard (1980) found that soil warming increased total leaf area.

In heat-tolerant tomatoes, the effect of root temperature on growth is not well documented. This may be attributed to the fact that, heat-tolerant tomatoes, which can be defined as cultivars which have the ability to set fruits at night temperatures not lower than $21^{\circ} \mathrm{C}$ (Abdalla and Verkerk, 1968), are limited to a few districts of the tropics.

This study was therefore conducted to evaluate

\footnotetext{
Received for publication 19 January 1993.
}

differences in growth (leaf area, shoot fresh and dry weight, relative growth rate and net assimilation rate) of young heat-tolerant and non heattolerant tomato cultivars and also to test how to change biomass or carbohydrate production (total plant dry weight regressed on net assimilation rate) between the two cultivars grown at four rootzone temperatures.

\section{Materials and Methods}

Two studies were conducted. Growth measurements were made in 4 root-zone temperature treatments in both studies. For both studies, 'Shuki', a heat-tolerant and 'Sataan', a non heat-tolerant tomato plants were grown in a glasshouse. The air temperatures were $35^{\circ}$ to $39^{\circ} \mathrm{C}$ (day) and $20^{\circ}$ to $22^{\circ} \mathrm{C}$ (night) measured with thermocouples shielded and aspirated at plant height in the center of the glasshouse.

Seeds were sown on July 30, 1991 in study 1 and August 8, 1991 in study 2. In both studies, three-week-old plants were placed in 9-liter pots containing complete nutrient solution (EC, $2.5 \mathrm{mS}$ $\cdot \mathrm{cm}^{-1}$ ). The pots were bathed in 4 water tanks maintained at temperatures of $15^{\circ}, 20^{\circ}, 25^{\circ}$ and 
$30^{\circ} \pm 0.5^{\circ} \mathrm{C}$ using heating coils and chillers. Each water tank was prepared to have ten pots of five 'Shuki' and five 'Sataan', independently. Each of the five plants per cultivar was considered as a replicate.

Plants were harvested 10 days later (day 31 ) in study 1 and 21 days later (day 42) in study 2 . The following parameters were measured: 1) leaf area (using a leaf area meter-type AAM-7, Hayashi Denki Co. Ltd.) and 2) fresh and dry weight of leaves, stems and roots.

At the start of each trial, 5 plants were sampled arbitrarily to give initial values for net assimilation rate (NAR) calculations. In the first trial, mean total dry weight and leaf area were $0.31 \mathrm{~g}$ and $71.6 \mathrm{~cm}^{2}$ per plant for 'Shuki' and $0.21 \mathrm{~g}$ and $40.9 \mathrm{~cm}^{2}$ per plant for 'Sataan', respectively. In the 2 nd trial, mean total dry weight and leaf area were $0.20 \mathrm{~g}$ and $71.0 \mathrm{~cm}^{2}$ per plant for 'Shuki' and $0.10 \mathrm{~g}$ and $41.0 \mathrm{~cm}^{2}$ for 'Sataan', respectively.

$N A R$ was calculated using the following equation: $\quad N A R=\left(W_{f}-W_{i}\right) /\left(A_{f}-A_{i}\right) \times \operatorname{In}\left(A_{i} / A_{i}\right) /\left(t_{2}-\right.$ $t_{1}$ ) (Radford, 1967; Evans, 1972) where. $W_{f}$ is the total plant dry weight at the end of the measurement period, $W_{i}$ is the total plant dry weight of initial measurement, $A_{f}$ is final leaf area, $A_{i}$ is initial leaf area, and $t_{2}-t_{1}$ is the time between measurements. Relative growth weight (RGR) was calculated from the equation: $R G R=\log \left(W_{t} / W_{i}\right) /\left(t_{2}-t_{1}\right)$; (Evans, 1972). Specific leaf area (SLA) was measured as the ratio of leaf area to leaf dry weight (LA/LDW), leaf weight ratio (LWR), as the ratio of leaf dry weight to total plant dry weight (LDW/TPDW), and leaf area ratio (LAR), as the ratio of leaf area to total plant dry weight (LA/TPDW).

Data were represented by analysis of variance and by simple regression analysis. Biomass or carbohydrate production between cultivars were determined for homogeneity of regression coefficients in accordance with the procedure adopted by Gomez and Gomez (1984).

\section{Results and Discussion}

Shoot fresh and dry weight, root dry weight and leaf area.

In study 1 (plants grown for 10 days after treatment) and study 2 (plants grown for 21 days after treatment), root-zone temperature and cultivar exerted independent influence on tomato growth for the primary response variables (shoot fresh weight, shoot dry weight, root dry weight and leaf area) (Tables 1 and 2). That is, RZT $\times$ Cultivar interactions was not significant with the exception of RZT $\times$ Cultivar for leaf area in plants grown for 21 days (Table 2).

Table 1 indicates that, shoot fresh and dry weight in plants grown for 10 days were highest at RZT of $30^{\circ} \mathrm{C}$. It also shows that, 'Shuki' had greater shoot and dry weight than 'Sataan'. Shoot

Table 1. Comparison of plant growth between heat-tolerant (cv. Shuki) and non heat-tolerant (cv. Sataan) tomato cultivars grown for 10 days at different root-zone temperatures (RZT).

\begin{tabular}{|c|c|c|c|c|c|c|}
\hline Cultivar & $\begin{array}{l}\mathrm{RZT} \\
\left({ }^{\circ} \mathrm{C}\right)\end{array}$ & $\begin{array}{l}\text { Shoot fresh } \\
\text { weight }(\mathrm{g})\end{array}$ & $\begin{array}{l}\text { Shoot dry } \\
\text { weight (g) }\end{array}$ & $\begin{array}{l}\text { Root dry } \\
\text { weight }(\mathrm{g})\end{array}$ & $\begin{array}{l}\text { Shoot/root } \\
\text { ratio }\end{array}$ & $\begin{array}{l}\text { Leaf area } \\
\left(\mathrm{dm}^{2}\right)\end{array}$ \\
\hline \multirow[t]{4}{*}{ Shuki } & 15 & $30.7(218)^{y}$ & $2.7(277)$ & $0.66(245)$ & 4.1 & $5.8(246)$ \\
\hline & 20 & $42.0(152)$ & $4.0(196)$ & $0.74(203)$ & 5.7 & $8.4(203)$ \\
\hline & 25 & $52.5(184)$ & $4.5(215)$ & $0.77(149)$ & 6.0 & $8.6(149)$ \\
\hline & 30 & $53.1(147)$ & $4.6(165)$ & $0.87(150)$ & 5.9 & $9.9(150)$ \\
\hline \multirow[t]{4}{*}{ Sataan } & 15 & 14.1 & 1.0 & 0.27 & 4.1 & 2.4 \\
\hline & 20 & 27.6 & 2.0 & 0.37 & 5.6 & 4.2 \\
\hline & 25 & 28.6 & 2.1 & 0.47 & 4.4 & 5.8 \\
\hline & 30 & 36.2 & 2.8 & 0.57 & 4.9 & 6.6 \\
\hline \multicolumn{7}{|c|}{ Significance ${ }^{z}$} \\
\hline \multicolumn{2}{|c|}{ Cultivar } & $* *$ & $* *$ & $* *$ & NS & $* *$ \\
\hline \multicolumn{2}{|l|}{ RZT } & $*$ & $*$ & $*$ & NS & $* *$ \\
\hline \multicolumn{2}{|c|}{ Cultivar $\times$ RZT } & NS & NS & NS & NS & NS \\
\hline
\end{tabular}

$z *, * *$, and $\mathrm{NS}$ indicate significance at $\mathrm{P}=0.05,0.01$ and nonsignificance at 0.05 respectively.

"Figures in parentheses indicate the percentage of values for 'Shuki" to those obtained for 'Sataan' at each temperature. 
Table 2. Comparison of plant growth between heat-tolerant (cv. Shuki) and non heat-tolerant (cv. Sataan) tomato cultivars grown for 21 days at different root-zone temperatures (RZT)

\begin{tabular}{lccclll}
\hline Cultivar & $\begin{array}{l}\text { RZT } \\
\left({ }^{\circ} \mathrm{C}\right)\end{array}$ & $\begin{array}{l}\text { Shoot fresh } \\
\text { weight }(\mathrm{g})\end{array}$ & $\begin{array}{l}\text { Shoot dry } \\
\text { weight }(\mathrm{g})\end{array}$ & $\begin{array}{l}\text { Root dry } \\
\text { weight }(\mathrm{g})\end{array}$ & $\begin{array}{l}\text { Shoot/root } \\
\text { ratio }\end{array}$ & $\begin{array}{l}\text { Leafarea } \\
\left(\mathrm{dm}^{2}\right)\end{array}$ \\
\hline Shuki & 15 & $80.2(218)$ & $7.6(250)$ & $1.14(194)$ & 7.2 & $20.2(194)$ \\
& 20 & $162.1(186)$ & $13.2(220)$ & $1.59(217)$ & 8.5 & $29.5(217)$ \\
& 25 & $205.6(188)$ & $14.3(203)$ & $1.77(174)$ & 8.2 & $34.1(174)$ \\
& 30 & $176.0(181)$ & $13.0(194)$ & $1.45(160)$ & 9.6 & $33.4(161)$ \\
Sataan & 15 & 36.8 & 3.0 & 0.57 & 5.4 & 10.4 \\
& 20 & 87.0 & 6.0 & 0.71 & 8.3 & 13.6 \\
& 25 & 109.6 & 7.0 & 0.73 & 9.7 & 19.6 \\
Significance & 30 & 97.1 & 6.7 & 0.70 & 9.5 & 20.8 \\
Cultivar & & $* *$ & $*$ & & & $*$ \\
RZT & $*$ & $*$ & $*$ & NS & $*$ \\
Cultivar $\times$ RZT & NS & NS & NS & NS & $*$ \\
\hline
\end{tabular}

****. and NS indicate significance at $\mathrm{P}=0.05 .0 .01$ and nonsignificance at 0.05 respectively.

* Figures in parentheses indicate the percentage of values for "Shuki" to those obtained for 'Sataan' at each temperature.

fresh weight of 'Shuki' was $118,52,84$ and $47 \%$ greater than that of 'Sataan' at $15^{\circ}, 20^{\circ}, 25^{\circ}$ and $30^{\circ} \mathrm{C}$, respectively. Shoot dry weight of 'Shuki' was $177,96,115$ and $65 \%$ greater than that of 'Sataan' at $15^{\circ}, 20^{\circ}, 25^{\circ}$, and $30^{\circ} \mathrm{C}$, respectively.

In Table 2, maximum shoot and dry weight were recorded at $\mathrm{RZT}$ of $25^{\circ} \mathrm{C}$ for both cultivars when grown for 21 days. Cultivar, 'Shuki' had significantly greater shoot fresh and dry weight than 'Sataan'. Shoot fresh weight of 'Shuki' was 118 . 86,88 and $81 \%$ greater than that of 'Sataan' at $15^{\circ}, 20^{\circ}, 25^{\circ}$, and $30^{\circ} \mathrm{C}$, respectively. Shoot dry weight of 'Shuki' was $150,120,103$ and $94 \%$ greater than that of 'Sataan' at $15^{\circ}, 20^{\circ}, 25^{\circ}$, and $30^{\circ} \mathrm{C}$, respectively. The greater increase in shoot dry weight of 'Shuki', may have resulted from larger leaf area and higher net assimilation rates or its ability to produce more carbohydrates than the non heat-tolerant cultivars 'Sataan'.

Root dry weight of 'Shuki' was significantly greater than that of 'Sataan' grown for 10 days (Table 1). The former was $145,103,49$ and $50 \%$ greater than the latter at $15^{\circ}, 20^{\circ}, 25^{\circ}$ and $30^{\circ} \mathrm{C}$ RZT respectively. Cultivar 'Shuki' recorded signi ficantly greater root dry weight than 'Sataan' at the end of 21 days as well as 10 days (Table 2). Root dry weight of 'Shuki' was 94, 117, 74 and $60 \%$ greater than that of 'Sataan' at $15^{\circ}, 20^{\circ}, 25^{\circ}$ and $30^{\circ} \mathrm{C}$ RZT, respectively. RZT had significant effect on root dry weight in plants grown for 10 days but no significant effect in plants grown for 21 days.

Root-zone temperature had no effect on the ratio of shoot to root dry weight and no differences were observed between cultivars (Tables 1 and 2). Shoot growth was affected more than root growth by RZT. Shoot dry weight was lower at $15^{\circ} \mathrm{C}$ compared to $30^{\circ} \mathrm{C}$ in both cultivars.

Leaf area response to RZT was similar to that of shoot fresh and dry weight in plants grown for 10 or 21 days. Treatment at $30^{\circ} \mathrm{C}$ resulted in maximum leaf growth in plants grown for 10 days (Table 1), while in plants grown for 21 days, the best leaf growth was at RZT of $25^{\circ}-30^{\circ} \mathrm{C}$ (Table 2). These results indicated that low RZT caused a considerable decrease in leaf area. The rate of increase in leaf growth was significantly greater in 'Shuki' than that in 'Sataan'. Root-zone temperature enhanced leaf growth of 'Shuki' by 146, 103, 49 and $50 \%$ as compared with that in 'Sataan' for 10 days of $15^{\circ}, 20^{\circ}, 25^{\circ}$ and $30^{\circ} \mathrm{C}$, respectively (Table 1). In plants grown for 21 days, leaf area of 'Shuki' was $94,117,74$ and $61 \%$ greater than that of 'Sataan' at $15^{\circ}, 20^{\circ}, 25^{\circ}$ and $30^{\circ} \mathrm{C}$, respectively (Table 2).

\section{Growth analysis}

In order to explain differences in growth and development between the heat-tolerant and non heat-tolerant cultivars, growth analysis was car. 
ried out for the secondary response variables such as RGR, NAR, LAR, SLA and LWR. The results indicated that root-zone temperature and cultivar also exerted independent influence since there was no interaction between RZT and Cultivar in both studies (Tables 3 and 4 ).

Relative growth rate can be separated into NAR and LAR. The mean RGR at the end of 10 days in cultivars was not significant (Table 3 ), but highly significant at the end of 21 days in cultivars or RZT (Table 4). Root-zone temperature had the largest influence on RGR at the end of 10 days (Table 3 ). This effect may have been caused by an acclimation period and/or a higher RZT suitable for young tomato plants. In Table 4, the plateau/decline of $\mathrm{RGR}$ at $30^{\circ} \mathrm{C}$ at the end of 21 days in both cultivars may indicate that RZT of $25^{\circ}-30^{\circ} \mathrm{C}$ was optimum for tomato plants. The

Table 3. Plant growth analysis of heat-tolerant (cv. Shuki) and non heat-tolerant (cv. Sataan) tomato cultivars grown for 10 days at different root-zone temperatures.

\begin{tabular}{|c|c|c|c|c|c|c|}
\hline Cultivar & $\begin{array}{l}\mathrm{RZT} \\
\left({ }^{\circ} \mathrm{C}\right)\end{array}$ & $\begin{array}{l}\text { RGR }\left(g^{*}\right. \\
\left.g^{-1} \cdot d a y^{-1}\right)\end{array}$ & $\begin{array}{l}\text { NAR }(g \\
\left.m^{-2} \cdot d a y^{-1}\right)\end{array}$ & $\begin{array}{l}\mathrm{LAR} \\
\left(\mathrm{cm}^{2} \cdot \mathrm{g}^{-1}\right)\end{array}$ & $\begin{array}{l}\text { SLA } \\
\left(\mathrm{cm}^{2} \cdot \mathrm{g}^{-1}\right)\end{array}$ & $\begin{array}{l}\mathrm{LWR} \\
\left(\mathrm{g} \cdot \mathrm{g}^{-1}\right)\end{array}$ \\
\hline \multirow[t]{4}{*}{ Shuki } & 15 & 0.25 & 12.9 & 172.5 & 258.8 & 0.56 \\
\hline & 20 & 0.26 & 14.3 & 179.6 & 340.5 & 0.57 \\
\hline & 25 & 0.28 & 15.7 & 164.0 & 335.4 & 0.51 \\
\hline & 30 & 0.29 & 14.9 & 181.6 & 331.5 & 0.54 \\
\hline \multirow[t]{4}{*}{ Sataan } & 15 & 0.19 & 10.0 & 188.6 & 277.6 & 0.69 \\
\hline & 20 & 0.25 & 14.0 & 179.4 & 294.0 & 0.60 \\
\hline & 25 & 0.25 & 11.5 & 202.1 & 395.9 & 0.62 \\
\hline & 30 & 0.28 & 14.0 & 215.4 & 351.0 & 0.59 \\
\hline \multicolumn{7}{|c|}{ Significance $^{x}$} \\
\hline Cultivar & & NS & NS & NS & NS & NS \\
\hline $\mathrm{RZT}$ & & NS & NS & NS & NS & NS \\
\hline Cultivar $x$ & RZT & NS & NS & NS & NS & NS \\
\hline $\begin{array}{ll}z & \text { NS:N } \\
y & \text { RGR }= \\
& \text { NAR }= \\
& \text { SLA }= \\
& \text { LAR = } \\
& \text { LWR }=\end{array}$ & $\begin{array}{l}\text { signific } \\
\text { lative } \\
\text { et assin } \\
\text { ecific l } \\
\text { af area } \\
\text { eaf wei }\end{array}$ & $\begin{array}{l}\text { ce at } \mathrm{P}=0 . \\
\text { wth rate. } \\
\text { tion rate. } \\
\text { area. } \\
\text { tio. } \\
\text { ratio. }\end{array}$ & & & & \\
\hline
\end{tabular}

Table 4. Plant growth analysis of heat-tolerant (cv. Shuki) and non heat-tolerant (cv. Sataan) tomato cultivars grown for 21 days at different root-zone temperatures.

\begin{tabular}{|c|c|c|c|c|c|c|}
\hline Cultivar & $\begin{array}{l}\mathrm{RZT} \\
\left({ }^{\circ} \mathrm{C}\right)\end{array}$ & $\begin{array}{l}\text { RGR }(g \cdot \\
\left.g^{-1} \cdot d a y^{-1}\right)\end{array}$ & $\begin{array}{l}\text { NAR (g. } \\
\left.\mathrm{m}^{-2} \cdot \mathrm{day}^{-1}\right)\end{array}$ & $\begin{array}{l}\text { LAR } \\
\left(\mathrm{cm}^{2} \cdot \mathrm{g}^{-1}\right)\end{array}$ & $\begin{array}{l}\text { SLA } \\
\left(\mathrm{cm}^{2} \cdot \mathrm{g}^{-1}\right)\end{array}$ & $\begin{array}{l}\text { LWR } \\
\left(\mathrm{g} \cdot \mathrm{g}^{-1}\right)\end{array}$ \\
\hline \multirow[t]{4}{*}{ Shuki } & 15 & 0.18 & 6.67 & 240.0 & 361.7 & 0.67 \\
\hline & 20 & 0.21 & 8.88 & 205.3 & 313.1 & 0.66 \\
\hline & 25 & 0.21 & 8.70 & 221.2 & 355.2 & 0.64 \\
\hline & 30 & 0.21 & 8.35 & 221.0 & 352.5 & 0.63 \\
\hline \multirow[t]{4}{*}{ Sataan } & 15 & 0.17 & 5.30 & 294.8 & 500.3 & 0.60 \\
\hline & 20 & 0.20 & 8.22 & 210.2 & 350.9 & 0.60 \\
\hline & 25 & 0.21 & 7.42 & 264.3 & 448.3 & 0.60 \\
\hline & 30 & 0.20 & 6.70 & 309.4 & 509.5 & 0.61 \\
\hline \multicolumn{7}{|c|}{ Significance ${ }^{z}$} \\
\hline \multicolumn{2}{|c|}{ Cultivar } & * & $* *$ & NS & $*$ & $*$ \\
\hline \multicolumn{2}{|c|}{$\mathrm{RZT}$} & $* *$ & $*$ & NS & NS & NS \\
\hline \multicolumn{2}{|c|}{ Cultivar $\times$ RZT } & NS & NS & NS & NS & NS \\
\hline
\end{tabular}

$\overline{2 *} * *$, and NS indicate significance at $P=0.05,0.01$ and nonsignificance at 0.05 respectively. 
higher growth rates of 'Shuki', at this stage may have resulted from more light interception due to larger leaf area and higher photosynthetic activity. The results may also indicate that heat-tolerant cultivars have higher growth rates than non heattolerant ones.

Net assimilation rate or photosynthetic efficiency is defined as the rate of increase in total dry matter per unit leaf surface. Results in Table 3 suggest that RZT of $25^{\circ} \mathrm{C}$ was optimum for NAR of 'Shuki' and $20^{\circ} \mathrm{C}$ for 'Sataan' at the end of 10 days, although no significant differences were observed between cultivars. Root-zone temperature had no effect on NAR in plants grown for 10 days. Table 4 shows that, significant differences in NAR were observed between cultivars at all RZT; heattolerant cultivars have higher NAR than non heattolerant cultivars when grown at a temperature range of $20^{\circ}$ to $30^{\circ} \mathrm{C}$. Our results also indicate that, NAR of young vegetative plants (10 days) were higher than that of older ones (21 days). These results agree with those obtained by Ito (1972) and Acock et al. (1990) who reported that, as plants grew, the leaves began to shade each other from light source which decreased the intensity to which leaves were exposed. This change has the effect of lowering the value of NAR for older plants and it may explain why the younger plants were more responsive to RZT (Tables 1 and 2). The photosynthetic efficiency of leaf area of plants grown for 10 days may not have been limited by light compared to that of plants grown for 21 days. Plants grown for 10 days had smaller leaf area than those grown for 21 days.

The capacity of plants to accumulate dry matter depends to a large extent on the size of the leaf surface in relation to the overall size of the plant. Leaf area ratio may be used in assessing effects of environmental conditions on the relative size of the assimilatory part. The leaf area ratio is the product of the ratio SLA $\times$ LWR. LAR in both stud ies, was nonsignificant between cultivars at all R2T and was numerically greater in 'Sataan', compared to that of 'Shuki' (Tables 3 and 4). SLA was significantly different between 'Shuki' and 'Sataan' during 10 days (Table 3). The results indicate that the heat-tolerant cultivar had thicker leaves as compared to that of the non heat-tolerant one. No significant difference was observed in plants grown for 21 days. Dry matter partitioning to the leaves (LWR) was not affected by RZT and differ ences between cultivars were not observed in plants grown for 10 days (Table 3 ) but differences between cultivars were found in plants grown for 21 days (Table 4). Greater dry matter was partitioned to the leaves of 'Shuki', compared to 'Sataan'. Greater assimilate partitioning may contribute to improvement of crop productivity by increasing total carbohydrate production or by favouring assimilate transfer to the harvestable portion of the crop.

\section{Correlations and regressions}

Pairwise correlation coefficinets calculated for the different growth parameters were possitive and significant at all RZT (data not shown). To determine which cultivar was a better carbohyrdrate producer at all RZT, total plant dry weight was regressed on NAR in plants grown for 10 or 21 days. Regression coefficients between the two cultivars were significantly different at RZT of $20^{\circ} \mathrm{C}$ and $25^{\circ} \mathrm{C}$ in plants grown for 21 days (Table 5).

Table 5. Regression coefficients of total plant dry weight on net assimilation rate (NAR) for heat-tolerant ( $c v$. Shuki) and non heat-tolerant (cv. Sataan) tomatoes grown for 10 and 21 days at different root-zone temperatures.

\begin{tabular}{|c|c|c|c|}
\hline \multirow{2}{*}{ Cultivar } & \multirow{2}{*}{$\begin{array}{l}\mathrm{RZT} \\
{ }^{\circ} \mathrm{C}\end{array}$} & \multicolumn{2}{|c|}{$\begin{array}{l}\text { Plant dry weight regressed } \\
\text { on NAR in plants grown for }\end{array}$} \\
\hline & & 10 days & 21 days \\
\hline Shuki & 15 & 0.28 & 1.35 \\
\hline Sataan & & 0.21 & 1.07 \\
\hline Significance $^{2}$ & & NS & NS \\
\hline Shuki & 20 & 0.16 & 1.67 \\
\hline Sataan & & 0.19 & 0.89 \\
\hline Significance & & NS & $*$ \\
\hline Shuki & 25 & 0.08 & 1.72 \\
\hline Sataan & & 0.21 & 0.79 \\
\hline Significance & & NS & $* *$ \\
\hline Shuki & 30 & 0.10 & 1.53 \\
\hline Sataan & & 0.24 & 1.13 \\
\hline Significance & & NS & NS \\
\hline
\end{tabular}

$* *, * *$, and NS: Significant at $\mathrm{P}=0.05,0.01$ and nonsignificant at 0.05 respectively using t-test of homogeneity for regressions $\mathrm{df}=6$. 
These results indicate that, 'Shuki', grown at $20^{\circ} \mathrm{C}$ or $25^{\circ} \mathrm{C}$ is a better carbohydrate producer than 'Sataan'.

Our results indicate that, the heat-tolerant cultivar is a better producer than the non heat-tolerant cultivar when exposed to high temperatures. This ability to produce more carbohydrates may be an important prerequisite for selection of tomato cultivar types for cultivation in the tropics and areas with summer conditions. The ability of heat-tolerant tomato cultivars to produce more carbohydrates may be related to their ability to produce high fruit yield compared to non heat-tolerant cultivars.

\section{Acknowledgement}

Financial support by the Ministry of Education, Science and Culture of Japan is gratefully acknowledged.

\section{Literature Cited}

Abdalla, A. A. and K. Verkerk. 1968. Growth, flowering and fruit set of tomatoes to high temperature. Nethr. J. Agric. Sci. 16:71-76.

Abdelhafeez, A. T., H. Harsemma, G. Veri and K. Ver. kerk. 1971. Effects of soil air temperature on growth, development and water use of tomatoes. Nethr. J. Agric. Sci. 19:67-75.

Acock, B., M. C. Acock and D. Pasternak. 1990. Interactions of $\mathrm{CO}_{2}$ enrichment and temperature on carbohydrate production and accumulation in muskmelon leaves. J. Amer. Soc. Hort. Sci. 115 : 525-529.

Cooper, A. J. 1974. Root temperature and plant growth. Commonwealth Agr. Bur. Slaugh, England.

Evans, G. C. 1972. The quantitative analysis of plant growth. Blackwell Scientific, Oxford, United King. dom.

Gomez, A. K. and A. A. Gomez. 1984. Statistical procedures for agricultural research (Second edition). John Wiley and Sons, New York.

Hurewitz. J. and H. W. Janes. 1983. Effect of altering the root-zone temperature on growth, translocation, carbon exchange rate, and leaf starch accumulation in the tomato. Plant Physiol. $73: 46-50$.

Ito, T. 1972. Photosynthetic activity of vegetable plants and its horticultural significance. V. Effects of supplementary $\mathrm{CO}_{2}$ or air movement upon the growth and yield of tomato and cucumber. J. Jap. Soc. Hort. Sci. $41: 42-50$.

Orchard, B. 1980. Effects of root and air temperature on growth and yield of tomatoes. Acta Hortic. 88 : $527-531$.

Radford. P. J. 1967. Growth analysis formulae-their use and abuse. Crop Science $7: 171-175$.

Yelle, S., A. Gosselin and M. J. Trudel. 1987. Effect of atmospheric $\mathrm{CO}_{2}$ concentration and root-zone temperature on growth, mineral nutrition, and nitrate reductase activity of greenhouse tomato. J. Amer. Soc. Hort. Sci. 112:1036-1040.

\title{
耐暑性ならびに非耐暑性トマト品種の初期生育に及ぼす根圈温度の影響
}

\author{
George Oduro Nkansah ·伊東 正 \\ 千菜大学園荎学部 271 千䈀県松戸市
}

\begin{abstract}
摘

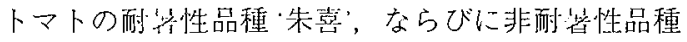
・サターン・を，異なる根圈温度下で栽培し，その生育 を調查した。根圈の温度は， $15^{\circ} ， 20^{\circ}, 25^{\circ}, 30^{\circ} \mathrm{C} の$ 4 水集に設定した，実験 $1 の$ 处理期間は 10 日間（播 種後 21〜31日）とし，実験 2では21日聞（播種後

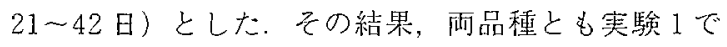

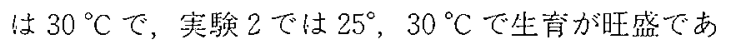

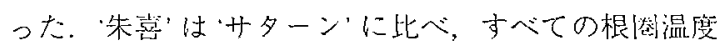
で地上部の生体重, 乾物重, 根の乾物重, 染面積が大
\end{abstract}

\section{要}

きかった。また，朱密”はすべての温度でサターン゙ に比べてNARが高かった，生育に関する調查項目間 にはいずれの品種も，すべての根圈温度で統計的な有 意差が諗められた。実騟 2 における淞乾物重, 炭水化

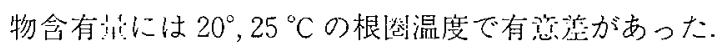

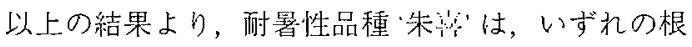
圈温度においても，通常の耐䜿性しか持たないサタ ーン・に比べて, 乾物および炭水化物の生座効率が優 れるものと推察した。 